DOI: 10.30842/ielcp230690152444

Andrea Scala
(State University of Milan)

\title{
SHORT AND LONG PRESENT INFLECTION IN ROMANI
}

\author{
А. Скала \\ (Миланский университет, Италия)
}

\section{Краткая и долгая флексии презента в цыганском языке}

В статье рассматриваются особенности употребления в цыганском языке кратких и долгих флексий, которые отличаются наличием показателя $-a$. В диалектах, в которых долгая форма выражает настоящее время, краткая является показателем сослагательного наклонения. В других диалектах, долгая форма выражает будущее время или специфические модальные значения, а краткая форма настоящее время. Только краткие флексии могут быть непосредственно возведены к средне- и древнеиндийским презентным окончаниям. Установление происхождения $-a$, отличающего долгие окончания, требует уточнения исходной функции этого показателя. В статье представлены свидетельства того, что исходно - $а$ было связано с прогрессивным значением, что, в частности, объясняет ограничение на его употребление со стативным глаголом ğan-/ğin- 'знать'. Предложенная для объяснения показателя - $а$ диахроническая связь между показателями прогрессива, футурума и презенса находит параллели в истории армянского языка.

Ключевые слова: цыганский язык, краткие и долгие флексии презента.

Romani dialects display in present tense two different inflection patterns, called respectively short present and long present. The latter differs from the former only in having a morpheme - $a$ (cfr. e.g. Kalderašitska sováv 'I sleep' vs Lombard Sinti sováva 'id.'). In the dialects in which the long form expresses present tense (Lombard Sinti, Arli, Burguği, Sepeči etc.), the short one usually has the value of an achronic subjunctive mood, mainly used in subordinated clauses. In other dialects (Erli, Kalderašitska, Lovaritska, Romungro, Finnish Romani etc.) the long form expresses future tense or some rare modal content, such as confirmative function, and the short one the present tense (Boretzky, Igla 1994: 394; Matras 2002: 156-157). From a historical point of view the short inflection is the only one that can be directly traced back to Middle and Old Indo-Aryan present inflection, cfr. e.g. sov- 'to sleep': $1 \mathrm{sg}$. sov-av $<$ MIA suvāmi, OIA svapāmi, 2 sg. sov-es < MIA suvasi, OIA svapasi, 3s sov-el < MIA suvadi, OIA svapati (Sampson 1926: 187- 
188; Matras 2002: 143-144; Benišek 2020: 33), while the long inflection, with its final $-a$, is surely an innovative form, whose original meaning is still debated. Yaron Matras maintains that the final - $a$ of the long present is and was uniquely an indicative mood marker that contrasts with the zero-marked subjunctive form (Matras 2001: 167; 2002: 155).

As for the etymology of the morpheme $-a$, it is very probable that it derives from a process of grammaticalization of some originally free and later cliticised form, but the very reduced phonological form makes difficult to individuate an ancestor in MIA or OIA; a first step in this way could be a better definition of the original meaning of $-a$ in verbal inflection. A wide exploration of the Romani dialects, made possible by the Romani Morpho-Syntax Database (https://romani.humanities.manchester.ac.uk/rms/), can provide some useful evidence for determining the original value of $-a$. In particular it is very remarkable that the verb ğan-/gin- 'to know' does not show the long inflection with $-a$ in those dialects in which the long form is the default form for present tense. This unexpected morphological irregularity could be a trace of some original content of the morpheme - $a$ that was incompatible with the inner semantic of a stative verb like 'to know'. As stative verbs are usually incompatible with progressive aspect (cfr. English I know but *I am knowing, Spanish yo se 'I know' but *yo estoy sabiendo), a possible hypothesis is that $-a$ was in origin a morpheme indicating progressive aspect. Put after the person-number markers of the old short present, the morpheme $-a$ probably added to the verbal form a progressive meaning, forming a progressive present. In the history of Romani this original meaning of $-a$ have gone lost and the long present would have become in some dialects a future tense, in other dialects the default form for present tense.

This supposed evolution finds a noteworthy typological parallel in the history of Armenian. In Western Armenian the old present of Classical Armenian (cfr. e.g. berem 'I bring') has become a subjunctive present ( $p^{h}$ erem), while the current present tense (gəp ${ }^{h}$ erem) originally was a progressive form. Interestingly, the same progressive form in Eastern Armenian (kəberem, where kə- is the Eastern variant of ga-) has developed a future meaning. Moreover, like in Romani, both in Western and Eastern Armenian the verb 'to know' has preserved its old form (Classical Armenian gitem, Eastern Armenian gitem, Western Armenian $k^{h}$ idem) without any trace of progressive marker (Vaux 1995:. 137). 


\section{Bibliography}

Beníšek, M. 2020: The Historical Origins of Romani. In: Matras, Ya., Tenser, A. 2020: The Palgrave Handbook of Romani Language and Linguistics. Cham: Palgrave Macmillan: 13-47.

Boretzky, N., Igla, B. 1994: Wörterbuch Romani-Deutsch-Englisch für den südosteuropäischen Raum. Wiesbaden: Harrassowitz.

Matras, Ya. 2001: Tense, aspect and modality categories in Romani. In: STUF. Sprachtypologie und Universalienforschung 54 (2), 162180.

Matras, Ya. 2002: Romani. A linguistic introduction. Cambridge: Cambridge University Press.

Sampson, J. 1926: The dialect of the Gypsies of Wales. Oxford: Clarendon Press.

Vaux, B. 1995: A Problem in Diachronic Armenian Verbal Morphology. In J. J. Weitenberg (ed.). New Approaches to Medieval Armenian Language and Literature. Amsterdam-Atlanta: Rodopi, 135-148. 